EASTERN REVIEW 2018, T. 7

\author{
Jacek Wojnicki
}

\title{
Restytucja samorządu lokalnego i regionalnego w państwach Europy Środkowej i Wschodniej
}

Artykuł poświęcony jest restytucji samorządów lokalnych i regionalnych w państwach Europy Środkowej i Wschodniej. Ukazuje główne kierunki formowania się administracji samorządowej w omawianych państwach postkomunistycznych.

Przedmiotem analizy jest grupa pięciu państw: Republiki Czeskiej, Słowacji, Węgier oraz Bułgarii i Rumunii. Niekiedy w tle prezentowanych analiz samorządowych odnajdujemy również wątki polskie. Co wspomniane państwa łączy - kilka elementów. Po pierwsze, państwa te należały do końca lat 80 . XX w. do wspólnoty socjalistycznej stanowiącej ważny element imperium zewnętrznego Związku Radzieckiego. Po drugie, od 1989 r. przechodziły - choć w zróżnicowanym tempie - proces szerokich i burzliwych przeobrażeń wewnętrznych obejmujących wiele aspektów funkcjonowania państwa. Po trzecie, nawiązywały do rozwiązań ustrojowych państw tzw. skonsolidowanych demokracji Europy Zachodniej oraz sięgały do własnych tradycji polityczno-ustrojowych. Reformy administracyjne, których ważnym elementem było przywrócenie władz samorządowych na poziomie lokalnym (i stworzenie ich odpowiedników na szczeblu regionalnym), stanowiły istotny człon przemian polityczno-ustrojowych ${ }^{1}$.

${ }^{1}$ Zob. J. Regulski, Samorzą III Rzeczypospolitej: koncepcje i realizacja, Warszawa 2000; M. Kulesza, D. Sześciło, Polityka administracyjna i zarzadzanie publiczne, Warszawa 2013; T. Kaczmarek, Struktury terytorialnoadministracyjne i ich reformy w krajach europejskich, Poznań 2005; R. Chrabąsz, J. Hausner, S. Mazur, Administracja publiczna w wybranych krajach Europy Środkowowschodniej, Kraków 2003; G. Rydlewski, Systemy administracji publicznej w państwach członkowskich Unii Europejskiej, Warszawa 2007; Administracja publiczna u progu XXI wieku: wyzwania i oczekiwania, red. J. Osiński, Warszawa 2011; Samorząd terytorialny w Europie Środkowej i Wschodniej, red. M. Barański, Katowice-Toruń 2009; E. Zieliński, Administracja rzadowa i samorzadowa w Polsce, Warszawa 2013; J. Wojnicki, Decentralizacja władzy publicznej w państwach Europy Środkowo-Wschodniej: aspekt ustrojowo-politologiczny, Warszawa 2014; A. Czyż, Samorząd terytorialny w państwach Grupy Wyszehradzkiej, Dąbrowa Górnicza 2010; Demokracja lokalna w państwach Europy, red. I. Bokszczanin, A. Mirska, Warszawa 2014. 
Podkreślić należy, iż reformy samorządowe zostały zainaugurowane w ramach federacji czechosłowackiej jesienią 1990 r., choć stosowne decyzje podejmowały już republikańskie parlamenty - Czeska Rada Narodowa oraz Słowacka Rada Narodowa.

Na mocy ustawy konstytucyjnej z 18 lipca 1990 r. skróceniu uległa kadencja komitetów narodowych. Stanowiły one wzorowane na modelu radzieckim jednostki administracji państwowej szczebla terenowego. Umożliwiło to restytucje samorządu lokalnego zarówno na ziemiach czeskich, jak i słowackich ${ }^{2}$. Istotnym momentem dla odrodzenia władz samorządowych na ziemiach czeskich była ustawa z dnia 4 października 1990 r. o gminach (nowelizowana następnie wiele razy) ${ }^{3}$. Oddzielna ustawa reguluje ustrój samorządowy stolicy Republiki - Pragi ${ }^{4}$. Pierwotne założenie przewidywało ustanowienie samorządu lokalnego na szczeblu gminnym, a następnym krokiem miało być usamorządowienie szczebla powiatowego (jak to stało się w Polsce w 1998 r.). Konstytucja z grudnia 1992 r. zdecydowała w sprawie dwustopniowej struktury administracji lokalnej - gminy oraz ziemi lub kraju. Opóźnienie realizacji deklaracji ustrojodawcy czeskiego spowodowane było dwoma - przeciwstawnymi - wizjami rozwoju państwowości czeskiej - samorządowej utożsamianej z pierwszym Prezydentem Republiki Vaclavem Havlem i centralistycznej, za którą opowiadał się pierwszy szef republikańskiego rządu Vaclav Klaus 5 .

Zróżnicowane tempo reformowania finansów lokalnych ilustruje podstawowe problemy nowych wspólnot lokalnych w państwach Europy Środkowej. W Republice Węgierskiej wspomniane procesy przebiegały w sposób ewolucyjny. W latach 80 . bowiem wprowadzono nowoczesny podatek od dochodów osobistych (mają w nim istotny udział samorządy gminne) oraz oparto rozdział dotacji na zestawie obiektywnych kryteriów. Z kolei w Polsce reforma finansów lokalnych została opóźniona w relacji do restytucji wspólnot gminnych o sześć miesięcy. W pierwszym okresie nowe gminy zostały zmuszone do funkcjonowania w oparciu o budżet centralny. Natomiast w Republice Czeskiej i na Słowacji reforma finansów lokalnych została przesunięta do stycznia 1993 r., co nałożyło się na powstanie dwóch organizmów państwowych ${ }^{6}$.

Podział kompetencji pomiędzy wspólnoty gminne na ziemiach czeskich i słowackich ukształtował się w sposób odmienny już od samego początku zmian

2 Zob. Z. Leoński, Samorząd terytorialny w Czechach, „Samorząd Terytorialny” 1993, nr 1/2, s. 102 oraz S. Balík, Komunální politika, Praha 2009, s. 55.

3 Zakon č. 367/1990 Sb.

${ }^{4}$ Zakon č. 418/1990 Sb.

5 Zob. K. Skotnicki, System konstytucyjny Czech, Warszawa 2000, s. 60.

${ }^{6}$ Zob. P. Swianiewicz, Stymulowanie lokalnej przedsiębiorczości, poprawa warunków bytu ludności czy pobożne życzenia? Charakterystyka polityk lokalnych w krajach Europy Środkowo-Wschodniej, [w:] Demokracja lokalna w krajach Europy Środkowo-Wschodniej, red. A. Miszczuk, Lublin 1995, s. 16. 
decentralizacyjnych. Dla przykładu, prowadzenie gospodarki wodnej w Republice Czeskiej należy do kompetencji samorządów gminnych, a w Słowacji zalicza się do uprawnień administracji państwowej. W porównaniu z kompetencjami administracji państwowej w pierwszym okresie funkcjonowania gmin słowackich (do 1998 r.) posiadały one ok. 15\% samodzielnych uprawnień. Natomiast nie został w pierwszym okresie powołany urząd centralny, który pilnowałby interesów wspólnot lokalnych ${ }^{7}$.

W pierwszych latach po aksamitnej rewolucji (listopad-grudzień 1989) można było dostrzec tendencję zmierzającą ku radykalnemu zwiększeniu liczby podstawowych jednostek samorządowych. I tak w 1989 r. na ziemiach czeskich było 4120 gmin, dwa lata później - 5768, a po kolejnych dwóch latach (w 1993 r.) - 6196. Od tamtego momentu liczba wspólnot gminnych w Republice Czeskiej ustabilizowała się na poziomie ok. $6300^{8}$. Tendencja powyższa wydaje się całkiem naturalna w pierwszym okresie po restytucji władz samorządowych. W mniejszej skali występowała również w innych omawianych państwach.

Jak zauważa Paweł Swianiewicz, powszechna praktyka w omawianym regionie polegała na fragmentaryzacji terytorialnej wynikającej z podziału dotychczasowych gmin. To zjawisko występowało w Republice Czeskiej, Słowacji, na Węgrzech oraz w kilku państwach bałkańskich: Macedonii, Chorwacji. Była to reakcja na wcześniejsze (w okresie rządów komunistycznych) przymusowe łączenie podstawowych jednostek terytorialnych, bez zachowania procedur demokratycznych. W latach 90. idea decentralizacji i autonomii terytorialnej była rozumiana dosłownie jako prawo każdej miejscowości do posiadania odrębnej wspólnoty samorządowej. W efekcie tego procesu rozdrabniania w wielu omawianych państwach część samorządów gminnych jest bardzo małych (poniżej tysiąca mieszkańców) ${ }^{9}$.

Warto zwrócić uwagę na odmienność regulacji czeskich w zakresie samorządowych zadań zleconych. W prawie czeskim zapisano, iż zlecanie może następować tylko na drodze regulacji ustawowych. Ustawodawca określa również środki finansowe niezbędne do wykonania wspomnianych zadań. W przypadku, gdy samorząd gminny nie był w stanie wykonać zadań zleconych, przejmował je urząd powiatowy. Po odzyskaniu możliwości wykonywania zadań zleconych przez gminę urząd powiatowy ponownie zwracał jej te zadania zlecone przez państwo. Przy wykonywaniu zadań zleconych samorząd gminny był związany przepisami ogólnymi uchwał rządu, wytycznymi centralnych organów administracji państwowej ${ }^{10}$.

7 Zob. P. Benuška, Reforma samorzadowa w Republice Czeskiej i Słowackiej, [w:] Demokracja lokalna..., s. 30 .

${ }^{8}$ Zob. K. Vodička, L. Cabada, Politický system České republiky. Historie a současnost, Praha 2011, s. 381.

9 Zob. P. Swianiewicz, Reformy konsolidacji terytorialnej - teoria i praktyka krajów Europy Środkowo-Wschodniej, „Samorząd Terytorialny” 2009, nr 4, s. 5.

${ }^{10}$ Zob. T. Rduch-Michalik, Wtadze lokalne w Republice Czeskiej, [w:] Wtadze lokalne w Europie Środkowej i Wschodniej. Gmina. Region. Samorzad, red. M. Barański, Katowice 1998, s. 47. 
Gminy według zasięgu kompetencji wykonywania zadań zleconych dzielimy na trzy podstawowe grupy. Do pierwszej kategorii można zaliczyć gminy, które wykonują podstawowy katalog zadań zleconych przez administrację państwową. Drugą grupę stanowią gminy, w których mieszczą się urzędy zlecone. Powyższe urzędy realizują zadania administracji państwowej dla kilku gmin (np. urząd stanu cywilnego oraz administracja budowlana). Trzecią grupę stanowią gminy powstałe po zniesieniu urzędów powiatowych. Często używa się w stosunku do nich określenia „małe powiaty”. Należy jednakże pamiętać, że realizują one zadania szczebla gminnego i nie stanowią drugiej instancji dla spraw realizowanych przez urzędy niższych kategorii, lecz wykonują wspomniane kompetencje, które realizowały urzędy powiatowe ${ }^{11}$.

Organem stanowiącym w czeskiej gminie jest przedstawicielstwo gminne, w miasteczkach - przedstawicielstwo miasteczka, a w miastach - przedstawicielstwo miejskie. Kadencja radnych trwa 4 lata, a elekcja lokalna jest definiowana przez następujące przymiotniki: powszechne, równe, bezpośrednie, proporcjonalne przeprowadzonew głosowaniu tajnym. Liczba radnych jest uzależniona od liczby mieszkańców i waha się od 5 do 55 . Wybory do przedstawicielstw gminnych zarządza prezydent najpóźniej na 90 dni przed zakończeniem bieżącej kadencji. Głosowanie odbywa się w ciągu dwóch dni (piątek i sobota), a elekcja nadzwyczajna - trwa tylko przez jeden dzieńn ${ }^{12}$.

Organem wykonawczym jest rada gminna wybierana przez przedstawicielstwo gminne, odpowiedzialna politycznie przed nim. Członkowie organu wykonawczego - w liczbie od 5 do 11 - rekrutują się spośród radnych do przedstawicielstwa. W skład rady gminnej wchodzą: starosta, zastępcy starosty oraz pozostali członkowie rady. Starosta zarządza posiedzenia rady, odpowiada za przygotowanie materiałów niezbędnych na posiedzenie rady. Posiedzenie rady jest zamknięte dla publiczności, ale z jego przebiegu sporządzany jest protokół jawny dla mieszkańców gminy. Przedstawicielstwo gminne ma prawo odwołać organ wykonawczy ${ }^{13}$.

Reforma samorządowa na ziemiach czeskich została przeprowadzona odmiennie niż w Polsce po 1990 r. Nie został bowiem powołany samorząd na szczeblu powiatowym, zaś terytorium wspólnot regionalnych jest mniejsze niż polskich województw. Aby przybliżyć administrację regionalną do obywatela, zwiększono

${ }^{11}$ Zob. P. Mrkývka, Władza lokalna w Republice Czeskiej, [w:] Władza i finanse lokalne $w$ Polsce $i$ krajach ościennych, red. E. Ruśkowski, B. Dolnicki, Bydgoszcz-Białystok-Katowice 2007, s. 135.

${ }_{12}$ Zob. A. Czyż, T. Rduch-Michalik, Samorzad terytorialny w Republice Czeskiej, [w:] Samorząd terytorialny..., s. 60 oraz S. Balík, Komunální..., s. 67.

${ }_{13}$ Zob. K. Lacina, Z. Vajdova, Local goverment in the Czech Republic, [w:] Decentralization: Experiments and Reform. Local Governms in Central and Eastern Europe, ed. T.M. Horváth, Budapest 2000, s. 268. 
liczbę samorządów krajowych z 7 do 14. Jednakże powołane jednostki regionalne są bardzo zróżnicowane pod względem: liczby mieszkańców, poziomu społeczno-gospodarczego oraz dochodów ludności. Na potrzeby statystyczne i porównawcze w odniesieniu do wspólnot regionalnych, a w szczególności w celu wykorzystywania funduszy unijnych, zostały utworzone jednostki NUTS II, które swoim obszarem i liczbą ludności przypominają terenowe organy administracji państwowej z 1960 r. $^{14}$

Najważniejszym organem w powiecie był urząd powiatowy. Na jego czele stał naczelnik, powoływany przez rząd na wniosek ministra spraw wewnętrznych. Urzędy przejęly zadania uprzednio działających (do 1990 r.) powiatowych komitetów narodowych oraz część kompetencji dawnych krajowych komitetów narodowych. Urzędy powiatowe stanowiły organy drugiej instancji w sprawach, w których decyzje administracyjne zapadały na szczeblu administracji gminnej, $\mathrm{z}$ wyjątkiem kwestii oświaty ${ }^{15}$.

Badacze czescy wymieniają kilka czynników wpływających na rozwój regionalny. Pierwszy to wertykalna i horyzontalna pozycja geograficzna danego regionu. W ramach pozycji wertykalnej wyróżniamy wielkie obszary metropolitalne, niemetropolitalne oraz regiony wiejskie. Horyzontalną pozycję można opisać jako tradycyjną oś zachód-wschód, odnoszącą się do poziomu rozwoju społeczno-gospodarczego. Drugim czynnikiem jest struktura gospodarcza i jej dywersyfikacja. Trzeci czynnik obejmuje jakość kapitału ludzkiego (jakość edukacji oraz posiadanie tradycji przedsiębiorczych). Czwarty element to natomiast jakość środowiska przyrodniczego (spustoszenie środowiska naturalnego na sporych obszarach państwa poważnie utrudnia przyszły rozwój regionalny) ${ }^{16}$.

Reforma regionalna była planowana w Republice Czeskiej od początku lat 90. Po pierwsze, zakładano, iż nowy szczebel samorządowy będzie odpowiedzialny za realizację następujących zadań: wykorzystywanie swojej władzy w ściśle określonych sferach transportu publicznego, budownictwa, finansów, regulacji działalności komercyjnej, ochrony środowiska, łowiectwa, prawa gruntowego, opieki społecznej, kultury, ochrony zdrowia, szkolnictwa, ochrony przeciwpożarowej i ogólnej administracji państwowej. Po drugie, do zadań regionów należałyby również funkcje kontrolne administracji państwowej wykonywane przez urzędy regionalne jako terenowe organy administracji państwowej. Po trzecie, zakładano, iż na szczeblu regionalnym możliwe będzie zapewnienie profesjonalnego doradztwa dla urzędów powiatowych przy wykonywaniu funkcji organów administracji państwowej. Po

${ }_{14}$ Zob. P. Mrkývka, Władza lokalna w Republice Czeskiej, [w:] Władza i finanse lokalne..., s. 134.

15 Zob. Z. Leoński, Ustrój organów administracji lokalnej na szczeblu powiatu w Czechach, „Samorząd Terytorialny” 1994, nr 5, s. 60.

${ }^{16}$ Zob. J. Blažek, Czynniki i kierunki rozwoju regionalnego Republiki Czeskiej podczas transformacji i w okresie przedakcesyjnym, „Samorząd Terytorialny” 2004, nr 2, s. 42. 
czwarte, nowy szczebel samorządowy miał występować jako organ odwoławczy od decyzji urzędów powiatowych zgodnie z ogólnymi regulacjami prawnymi ${ }^{17}$.

Rozstrzygnięcie kwestii umiejscowienia drugiego szczebla samorządu terytorialnego nastąpiło w grudniu 1997 r. po upadku centralistycznego rządu kierowanego przez Vaclava Klausa ${ }^{18} .23$ października 1997 r. Izba Poselska, a 3 grudnia $1997 \mathrm{r}$. Senat uchwalił ustawę konstytucyjną o utworzeniu wyższych jednostek samorządu terytorialnego oraz o zmianie konstytucji ${ }^{19}$. Należy przy okazji zwrócić uwagę na zapisany 24-miesięczny okres vacatio legis. Kolejną poważną zmianą w działalności samorządowych gmin było uchwalenie nowej regulacji - ustawy o gminach z 12 kwietnia 2000 r. $^{20}$, która weszła w życie z dniem elekcji do organów przedstawicielskich samorządów krajowych, tj. 12 listopada $2000 \mathrm{r}$.

Od 1 stycznia 2000 r. Republika Czeska dzieli się na 14 samorządów krajowych, włącznie z Pragą jako miastem wydzielonym ${ }^{21}$. Zalicza się do nich następujące samorządy regionalne: środkowoczeski, południowoczeski, pilzneński, karlowowarski, ujski, liberecki, karlowohradecki, pardubicki, wysoczyzna, południowomorawski, ołomuniecki, morawskośląski i zliński. Dodatkowo od stycznia 2003 r. został wprowadzony podział na 205 gmin o poszerzonych kompetencjach. Powiaty przestały pełnić zadania jednostki administracji państwowej, zachowano je jako siedziby administracji sądowej, policji oraz niektórych urzędów państwowych ${ }^{22}$.

Z kolei na Słowacji ustawy samorządowe zostały uchwalone na posiedzeniu republikańskiego parlamentu w dniu 6 września 1990 r. - ustawa o ustroju gminy i o zmianie niektórych ustaw ${ }^{23}$. Oddzielne dwie regulacje ustawowe odnoszą się do ustrojów samorządowych dwóch największych ośrodków miejskich - Bratysławy oraz Koszyc ${ }^{24}$.

Gminę tworzy, likwiduje, dzieli oraz łączy Rząd Republiki w drodze rozporządzenia. Decyzja jest podejmowana po uprzedniej zgodzie wspólnoty gminnej oraz stanowiska samorządu krajowego, na którego terenie znajduje się dana gmina. Kilka gmin może połączyć się w jedną jednostkę samorządową, w analogiczny sposób gmi-

${ }_{17}$ Zob. K. Lacina, Podstawowe informacje o władzach lokalnych w Republice Czeskiej, [w:] Władze lokalne w Europie Centralnej i Wschodniej oraz we Wspólnocie Niepodległych Państw, Budapeszt 1994, s. 72.

${ }_{18}$ Zob. T. Rduch-Michalik, Czechy, [w:] Władza państwowa i administracja publiczna w państwach Europy Środkowej i Wschodniej, red. M. Barański, Toruń 2007, s. 64.

19 Zakon č. 347/1997 Sb.

20 Zakon č. 128/2000 Sb.

${ }^{21}$ Zob. K. Vodička, L. Cabada, Politický system České republiky. Historie a současnost, Praha 2011, s. 395 oraz J. Bureš, J. Charvát, P. Just, M. Štefek, Česká demokracie po roce 1989. Institucionálni základy českého politického systemu, Praha 2012, s. 175.

${ }^{22}$ Zob. A. Jakubowska, Czechy, [w:] Nowa dziesiątka Unii Europejskiej, red. D. Jędrzejczyk, Warszawa 2005, s. 69.

${ }^{23}$ Zakon č. 369/1990 Z.z. oraz M. Posluch, L. Cibulka Štátne právo Slovenskej republiky, Šamorín 2006, s. 121-127.

${ }^{24}$ Zakon č. 377/1990 Z.z. oraz zakon č. 401/1990 Z.z. 
na może być podzielona na dwie lub więcej gmin. Połączyć lub podzielić samorządy gminne można tylko ze skutkiem na dzień elekcji samorządowej do władz lokalnych ${ }^{25}$.

Podobnie jak na ziemiach czeskich - organem przedstawicielskim jest przedstawicielstwo gminne. Składa się ono z radnych wyłonionych w bezpośredniej elekcji przez mieszkańców wspólnoty lokalnej. Liczbę radnych ustala samo przedstawicielstwo na podstawie liczby mieszkańców. W najmniejszych wspólnotach gminnych (liczących do 40 osób) liczy ono 3 radnych, a maksymalnie może liczyć 41 radnych w miastach powyżej 100 tys. mieszkańców. Przedstawicielstwo gminne obraduje przynajmniej raz na dwa miesiące lub na posiedzeniach nadzwyczajnych, które zwołuje starosta na swój wniosek lub grupy, co najmniej $1 / 3$ rady. Wówczas posiedzenie odbywa się w ciągu 10 dni od daty wniosku ${ }^{26}$. Warto zaznaczyć, iż kształt koalicji partyjnych na poziomie lokalnym jest całkiem odmienny od koalicji partyjnych na poziomie ogólnopaństwowym. Partie zasiadające w koalicjach tworzących gabinety rządowe na forum Rady Narodowej Republiki Słowackiej są często w opozycji na poziomie lokalnym ${ }^{27}$.

Natomiast organem wykonawczym jest starosta gminy, wyłaniany w elekcji bezpośredniej. Kandydat musi mieć ukończone 25 lat, posiadać czynne i bierne prawo wyborcze, miejsce zamieszkania w danej wspólnocie gminnej oraz spełniać podobne wymogi jak radny przedstawicielstwa. Do zadań starosty zaliczamy również: reprezentowanie gminy na zewnątrz, pełnienie obowiązków statutowego organu $\mathrm{w}$ zakresie majątkowo-prawnym oraz w stosunku do pracowników gminy - kierownik urzędu gminy. W stosunkach administracyjnych jest organem administracji. Jego funkcji nie można łączyć z innymi stanowiskami państwowymi i samorządowymi, takimi jak: prokurator, sędzia, policjant, pracownik gminny, główny kontroler gminy czy pracownik urzędu krajowego. W miastach liczących powyżej 200 tys. mieszkańców organem wykonawczym jest primátor ${ }^{28}$. Republika Słowacka podzielona jest na 79 okręgów skupionych wokół 8 samorządów krajowych. Kraj bratysławski i trnawski zajmują południowo-wschodni kraniec Republiki. Bardziej centralnie położony jest kraj nitrzański i na północ leżący kraj trenczański. Sąsiaduje z nim, usytuowany w północno-środkowej części państwa, kraj żyliński, z którym graniczy kraj bańskobystrzycki. Z kolei we wschodniej części Republiki umiejscowione zostały kraje koszycki oraz preszowski ${ }^{29}$.

${ }^{25}$ Zob. V. Babčák, Władza lokalna w Republice Stowackiej, [w:] Władza i finanse lokalne..., s. 292.

${ }^{26}$ Zob. M. Barański, Samorzad terytorialny w Republice Stowacji, [w:] Samorzad terytorialny..., s. 60 oraz E. Láštic, Územná samospráva, Bratislava 2010, s. 34.

${ }^{27}$ Zob. J. Nemec, P. Bercik, P. Kuklis, Local Goverment in Slovakia, [w:] Decentralization: Experiments and Reform..., s. 315.

${ }_{28}$ Zob. G. Chmielewski, System konstytucyjny Słowacji, Warszawa 2014, s. 106 oraz E. Láštic, Územná..., s. 36.

${ }^{29}$ Zob. E. Kaczmarska, Stowacja, [w:] Nowa dziesiątka..., s. 438 oraz A. Bröstl a kolektív, Ústavné právo Slovenskej republiky, Plzeň 2010, s. 211-215. 
Jak podkreśla Marek Barański, sytuacja prawna oraz praktyka funkcjonowania władz lokalnych na Słowacji nie uległy istotnym zmianom do 1992 r. Normy ogólne odnoszące się do praw i kompetencji mieszkańców, w tym również organów gminy w sytuacji braku aktów szczegółowych, w warunkach istnienia silnej i scentralizowanej administracji rządowej nie chroniły władz samorządowych przed naciskami ze strony administracji państwowej szczebla centralnego ${ }^{30}$.

Od 1991 r. rozpoczęto prace przygotowawcze do drugiego etapu reformy lokalnej administracji publicznej. Wytyczne reformy obejmowały następujące elementy: 1) rozwój demokracji lokalnej i zaangażowania obywateli w podejmowanie decyzji; 2) kontynuacja decentralizacji poprzez przekazywanie kompetencji władzom samorządowym i regionalnym i dokonanie zmian $\mathrm{w}$ zasadach finansowania powyższych zadań publicznych; 3) usprawnienie systemu finansów władz samorządowych dla ułatwienia im realizacji nowych zadań; 4) wdrożenie bardziej efektywnego systemu organizacji struktur lokalnej administracji publicznej oraz 5) optymalizacja nowych struktur terytorialnych i administracyjnych w Republice Słowacji. Nowy rząd pod kierunkiem Josefa Moravčika (marzec 1994) proponował stopniowe wprowadzanie reform administracyjnych w perspektywie od 4 do 8 lat (jedna lub dwie kadencje) ${ }^{31}$.

Bardziej precyzyjne regulacje odnoszące się do władz samorządowych wprowadzono do słowackiej konstytucji w lutym 2001 r., gdy rozstrzygnięto również ostatecznie kwestie ustanowienia samorządów krajowych na mocy ustawy z 4 lipca $2001 \mathrm{r}^{32}$

Model węgierskiej reformy administracyjnej był odmienny od opisanych powyżej przypadków czeskiego oraz słowackiego. Zgromadzenie Krajowe na posiedzeniu w dniu 2 sierpnia 1990 r. uchwaliło ustawę o samorządzie terytorialnym oraz ordynacje wyborcze do rad samorządowych oraz urzędów burmistrzowskich ${ }^{33}$. Reforma administracyjna przesądziła już w pierwszym etapie o dwuszczeblowej strukturze administracji samorządowej - gminnym oraz komitackim. Pewne korekty w strukturze organizacyjnej były wprowadzane w latach następnych.

Organem przedstawicielskim w gminie jest rada. Regulacje ustawowe stanowiły, iż część praw i obowiązków rada gminy może przekazać innym organom administracji publicznej - burmistrzowi, jej komitetom (organom wewnętrznym rady), organom dzielnic miejskich oraz organom samorządowym mniejszości etnicznych. Jednakże pewne kompetencje nie mogą być delegowane innym organom i są wyłączne przeznaczone dla rady gminnej - stanowienie rozporządzeń, zarządzanie gminnego re-

30 Zob. M. Barański, Stowacja. Podstawy ustrojowe systemu politycznego. Partie polityczne w stowackim parlamencie, [w:] Dynamika systemów politycznych wybranych państw Europy Środkowej i Wschodniej, red. M. Barański, Katowice 1995, s. 67.

${ }^{31}$ Zob. S. Capkova, Podstawowe informacje o władzach lokalnych na Stowacji, [w:] Władze lokalne w Europie Centralnej i Wschodniej..., s. 198.

32 Zakon č. 302/2001 Z.z.

${ }^{33}$ Act LXV of 1990 oraz Act LXIV of 1990. 
ferendum, tworzenie organów samorządu lokalnego, zgoda na podjęcie współpracy z innymi jednostkami lokalnymi oraz tworzenie lokalnej administracji ${ }^{34}$.

Struktura organu wykonawczego wedle pierwotnych regulacji ustawowych z 1990 r. była hybrydowa i uzależniona od liczby ludności w jednostce lokalnej. W gminach zamieszkiwanych przez mniej niż 10 tys. obywateli burmistrz stanowił jednoosobowy organ wykonawczy i był wybierany przez mieszkańców w elekcji bezpośredniej. Z kolei w gminach większych organ wykonawczy był kolegialny i powoływany przez radnych. Rada samorządowa mogła wybierać również wiceburmistrza lub więcej niż jednego. W postaci aparatu pomocniczego występował urząd burmistrzowski ${ }^{35}$.

Organ wykonawczy - burmistrz - stoi na czele administracji lokalnej, jest z urzędu przewodniczącym rady samorządowej na szczeblu lokalnym oraz reprezentuje gminę na zewnątrz. Do jego uprawnień należy zwoływanie i przewodniczenie posiedzeniom rady. Obok zadań przynależnych do władz samorządowych burmistrz może wykonywać zadania z zakresu administracji państwowej. Musi to jednakże wynikać z regulacji ustawowych, rozporządzeń rządowych wydanych na podstawie upoważnienia ustawowego. Burmistrz obejmuje swoje obowiązki po złożeniu przysięgi przed radą samorządową ${ }^{36}$.

Oddzielna regulacja ustawowa odnosiła się do statusu administracyjnego stolicy państwa - Budapesztu ${ }^{37}$. Struktura samorządowa tego największego węgierskiego miasta była dualistyczna. Autonomiczne kompetencje posiadała administracja miejska oraz administracje 23 dzielnic miasta, jako jednostek pomocniczych. Kompetencje miasta zostały podzielone na ogólnomiejskie (za nie odpowiadał samorząd miasta) oraz na lokalne, za które odpowiadały samorządowe dzielnice. Władzę wykonawczą w Budapeszcie sprawował nadburmistrz miasta wybierany przez mieszkańców w drodze powszechnej elekcji, natomiast na szczeblu każdej z dzielnic zarządzał burmistrz ${ }^{38}$.

W 1994 r., a więc po ukończeniu pierwszej kadencji władz samorządowych, dokonano trzech istotnych modyfikacji w strukturze administracji lokalnej i regionalnej. Po pierwsze - wprowadzono bezpośrednie wybory burmistrzów we wszystkich węgierskich gminach. Po drugie - wzmocniono kompetencje samorządu komitackiego, definiując go jako jednostkę administracji regionalnej i przyznając mu nowe zadania publiczne. Wybory do walnego zgromadzenia stały się elekcją bezpośrednią i powszechną. A po trzecie - zlikwidowano instytucje komi-

${ }^{34}$ Zob. I. Temesi, Local Goverment in Hungary, [w:] Decentralization: Experiments and Reform..., s. 358 .

${ }^{35}$ Zob. W. Brodziński, System konstytucyjny Wegier, Warszawa 2003, s. 69.

${ }^{36}$ Zob. A. Czyż, R. Glajcar, K. Krysieniel, Wegry, [w:] Władza państwowa i administracja publiczna..., s. 334.

${ }^{37}$ Act of XXIV/1991.

${ }^{38}$ Zob. I. Temesi, Local Goverment in Hungary, [w:] Decentralization: Experiments and Reform..., s. 350 . 
sarzy republiki, którzy funkcjonowali w ośmiu regionach administracyjnych jako organy nadzoru. Wprowadzono urzędy administracji publicznej, a ich kierownicy pełnili funkcje nadzorcze w stosunku do gmin i komitatów ${ }^{39}$.

$\mathrm{Na}$ szczeblu wojewódzkim (komitackim) powoływano w trybie pośrednim - walne zgromadzenie wojewódzkie spośród delegatów gminnych w liczbie - 1 członek zgromadzenia na 10 tys. mieszkańców. Do zadań walnego zgromadzenia należał wybór przewodniczącego. Należy dodać, iż pełnił on dwie istotne funkcje publiczne - był jednoosobowym organem wykonawczym oraz reprezentował samorząd komitacki na zewnątrz. Wybór przewodniczącego oraz jego zastępcy następował w głosowaniu tajnym większością 2/3 głosów. W województwie tworzony był urząd komitacki w charakterze aparatu pomocniczego. W relacjach wobec pracowników urzędu przewodniczący pełnił zadania zwierzchnika służbowego. Węzłowym zadaniem urzędu komitackiego było fachowe przygotowywanie stosownych decyzji administracyjnych oraz organizacja i kontrola ich wykonania ${ }^{40}$.

Obecne terytorium Węgier obejmuje zaledwie 1/3 obszaru dawnych, historycznych Węgier. Państwo jest podzielone na 19 komitatów oraz jedno miasto wydzielone - Budapeszt. Oprócz aglomeracji budapesztańskiej na Węgrzech znajdujemy 20 innych ośrodków miejskich funkcjonujących na prawach komitackich $^{41}$.

Komunalizacja lub prywatyzacja własności państwowej stanowiła na przełomie lat 80. i 90. XX w. jedną z najistotniejszych zmian na szczeblu lokalnym. Dawne, należące do państwa, socjalne budynki mieszkalne, ujęcia wody, lasy, przedsiębiorstwa usług publicznych i komercyjne, budynki i grunty publiczne zostały przekazane władzom lokalnym na mocy regulacji ustawowych. Natomiast dochody pochodzące z prywatyzacji przedsiębiorstw komunalnych były następnie dzielone pomiędzy budżety lokalne i budżet centralny. Samorządy gminne zostały właścicielami prywatyzowanych przedsiębiorstw na zasadzie własności terenów, na których się one znajdowały ${ }^{42}$.

Reforma samorządowa w Bułgarii została wprowadzona jesienią 1991 r. Ordynacja wyborcza do Zgromadzenia Narodowego oraz organów lokalnych została uchwalona 20 sierpnia 1991 r., a pierwszą elekcję samorządową przeprowadzono 13 października $1991^{43}$. Sytuacja prawna władz samorządowych została określona w ustawie o samorządzie terytorialnym i administracji lokalnej ${ }^{44}$.

39 Zob. A. Czyż, Samorzą terytorialny w Republice Węgier, [w:] Samorząd terytorialny..., s. 256.

${ }^{40}$ Zob. E. Olejniczak-Szałowska, Zadania i ustrój samorzadu terytorialnego na Węgrzech, „Samorząd Terytorialny” 1992, nr 9, s. 56.

${ }^{41}$ Zob. A. Rosłonek, Wegry, [w:] Nowa dziesiątka..., s. 540.

${ }^{42}$ Zob. T.M. Horvath, Podstawowe informacje o władzach lokalnych na Wegrzech, [w:] Wtadze lokalne w Europie Centralnej $i$ Wschodniej..., s. 99.

${ }^{43}$ Zob. Butgaria. Przemiany konstytucyjne w Europie Wschodniej, t. I, red. R. Chruściak, Warszawa 1993, s. 57-69.

${ }^{44}$ Drżawen Westnik nr 77 z 1991 r. 
Administracyjno-terytorialne jednostki powstały w Bułgarii przy uwzględnieniu następujących przesłanek - historycznej, geograficznej, ekonomicznej, socjalnej, demograficznej i ekologicznej. Tworzenie i likwidacja jednostek administracyjno-terytorialnych następowała $\mathrm{w}$ drodze regulacji ustawowych po uprzednim zasięgnięciu opinii mieszkańców. Powołując do życia nową gminę, elekcja do rady gminnej była przeprowadzana w terminie do trzech miesięcy od jej utworzenia. Gmina jest definiowana jako podstawowa jednostka administracyjno-terytorialna, w której jest realizowany samorząd lokalny ${ }^{45}$.

Na szczeblu podstawowym organem stanowiącym jest rada gminna. Radni powoływani są na 4 lata w drodze wyborów bezpośrednich i powszechnych, przy użyciu proporcjonalnego rozdziału mandatów. Kandydat powinien stale zamieszkiwać na terenie gminy, w której kandyduje. Liczba radnych została uzależniona od liczby wyborców w danej gminie. W najmniejszych - liczących do 5 tys. mieszkańców - wybiera się 11 radnych; w średniej gminie - odpowiednio do 30 tys. mieszkańców - 21 radnych, a do 50 tys. mieszkańców - 29 radnych, z kolei w największych gminach liczących powyżej 160 tys. mieszkańców -51 radnych $^{46}$.

Natomiast organem wykonawczym jest wójt (kmet) wyłaniany w elekcji powszechnej i bezpośredniej. Rada gminna może podjąć decyzje w sprawie wyborów wójtów w poszczególnych miejscowościach na terenie danej jednostki lokalnej. Na wniosek kmeta rada wybiera w tajnym głosowaniu jego zastępców. Rada gminna posiada uprawnienie do zmiany rozporządzenia wójta w przypadku stwierdzenia naruszenia jej uprawnień. W takim przypadku wójt może złożyć protest na decyzje radnych, ale w przypadku powtórnego pozytywnego głosowania w radzie obliguje to wójta do realizacji decyzji radnych ${ }^{47}$.

Reforma administracyjna z początku lat 90. wprowadziła definicję własności komunalnej (na mocy nowelizacji ustawy o własności). Powyższa reforma legislacyjna zaczęła eliminować system totalnej kontroli państwa nad prawem własności. Nowe regulacje ustawowe określała w sposób dość ogólny jako obiekty, które powinny być przekazane nowym władzom lokalnym. Własność komunalna miała stanowić naturalną bazę do rozpoczynania działalności przedsiębiorstw komunalnych, które powinny tworzyć dodatkowe środki finansowe dla samorządów lokalnych ${ }^{48}$.

Podział administracyjny kraju ustanowiony w 1991 r. przetrwał tylko przez cztery lata. Poważny kryzys społeczno-gospodarczy, którego symptomy ujawniły się w latach 90., poddały pod wątpliwość rozbudowany system administracji samorządowej. Zastrzeżenia budził dualizm zarządzania na szczeblu powiatowym.

${ }^{45}$ Zob. M. Żmigrodzki, Administracja publiczna i samorzad terytorialny w Republice Butgarii, [w:] Demokracja lokalna..., s. 38.

${ }^{46}$ Zob. J. Karp, M. Grzybowski, System konstytucyjny Butgarii, Warszawa 2002, s. 76.

${ }^{47}$ Zob. E. Pioskowik, Bułgaria. Rola organów przedstawicielskich $w$ systemie rząów na szczeblu centralnym i terenowym, [w:] Dynamika systemów politycznych..., s. 30.

${ }^{48}$ Zob. S. Kyutchukov, Podstawowe informacje o władzach lokalnych w Republice Bułgarii, [w:] Władze lokalne w Europie Centralnej i Wschodniej..., s. 44. 
Dublowanie bowiem kosztów utrzymania administracji państwa (finansowanej z budżetu centralnego) oraz władz samorządowych (finansowanych z budżetów lokalnych) skutkowało podwojeniem uprawnień organów rządowych oraz samorządowych. Powodowało to liczne spory kompetencyjne oraz wzrost wydatków publicznych na funkcjonowanie administracji powiatowej ${ }^{49}$.

Do lat 90. XX w. w Republice Bułgarii funkcjonował podział na dziewięć okręgów, obejmujący również miasto wydzielone - Sofia. Okręgi dzieliły się z kolei na powiaty i gminy. W okresie postkomunistycznej transformacji dokonano reformy administracyjnej, w wyniku której utworzono 28 obwodów. Na czele administracji obwodowej stoją naczelnicy mianowani przez Radę Ministrów. Korzystają ze środków przydzielanych z budżetu centralnego w celu sprawniejszego planowania regionalnego i wykorzystywania funduszy unijnych ${ }^{50}$.

Reforma administracyjna w Rumunii została przeprowadzona dopiero jesienią $1991 \mathrm{r}$., gdy w regulacjach konstytucyjnych rozstrzygnięto kwestie podziałów terytorialnych oraz konstrukcji władz samorządowych. Przesądzono wówczas o dwuszczeblowej konstrukcji władz lokalnych (podobnie jak w sąsiednich Węgrzech) - na samorząd gminny oraz wojewódzki. Ustawa konstytucyjna z listopada $1991 \mathrm{r}$. wprowadziła - wzorując się na przykładzie francuskiej V Republiki - kategorie ustaw organicznych. Odnoszą się one m.in. do kwestii statusu urzędników publicznych, postępowania w sprawach administracyjnych, organizacji administracji lokalnej, podziału administracyjnego oraz ogólnych zasad funkcjonowania samorządów lokalnych ${ }^{51}$. Parlament rumuński uchwalił wówczas kluczowe regulacje ustawowe - ustawę o lokalnej administracji publicznej oraz o lokalnych wyborach ${ }^{52}$. W maju 1994 r. parlament Rumunii uchwalił kolejną ważną ustawę - o podatkach lokalnych ${ }^{53}$.

W Rumunii funkcjonuje trójstopniowy podział administracyjno-samorządowy. Najniższe szczeble administracji stanowią gminy, pośredni - okręgi administracyjne, a najwyższy - województwo. Gminami, których w 2004 r. w Rumunii było 2686, zarządzają urzędnicy zwani primarami. Wyższym szczeblem administracyjnym są terenowe okręgi administracyjne w liczbie 272. Najwyżej w strukturze administracyjnej ulokowane są województwa, których jest 41 oraz jedno miasto wydzielone - Bukareszt ${ }^{54}$.

${ }^{49}$ Zob. E. Pioskowik, Władza lokalna w Butgarii, [w:] Władze lokalne w Europie Środkowej i Wschodniej. Gmina..., s. 21.

${ }_{50}$ Zob. A. Koseski, Butgarska transformacja, [w:] Przemiany w Europie Środkowo-Wschodniej. 20 lat doświadczeń, red. A. Koseski, J. Wojnicki, Pułtusk 2011, s. 196.

${ }^{51}$ Zob. W. Skrzydło, Republika Rumunii, [w:] Ustroje państw współczesnych, t. 2, red. E. Gdulewicz, Lublin 2002, s. 171.

${ }_{52}$ Monitorul Oficial, maj 1994.

${ }_{53}$ Monitorul Oficial, listopad 1991.

${ }^{54}$ Zob. A. Koseski, M. Willaume, Nowe kraje Unii Europejskiej. Butgaria, Rumunia, Warszawa 2007 , s. 86. 
Organami stanowiącymi i kontrolnymi w gminach oraz miastach są rady lokalne. Jednostki samorządu wybierane są na 4-letnią kadencję, która może zostać przedłużona tylko w dwóch przypadkach - na wypadek wojny lub katastrofy o ogólnokrajowych skutkach. Liczba radnych jest uzależniona od liczby mieszkańców. Pracami rady samorządowej kieruje przewodniczący. Jest on wybierany większością ustawowego składu rady. Decyzje na forum rady zapadają zwykle większością głosów. Jednakże w najistotniejszych kwestiach ustawodawca wymaga do podjęcia decyzji większości 2/3 składu rady lokalnej.

Mandat radnych trwa cztery lata. Rada lokalna zbiera się na posiedzenia zwyczajne raz w miesiącu. $Z$ kolei na posiedzenie nadzwyczajne rada samorządowa może się zebrać na wniosek mera lub co najmniej grupa $1 / 3$ ustawowej liczby radnych. Posiedzenie rady jest prawomocne w przypadku udziału w nim większości radnych. Uczestnictwo wposiedzeniach rady jest obowiązkowe, niedopuszczalna jest obecność na pięciu kolejnych posiedzeniach lub kolejnych trzech nadzwyczajnych ${ }^{55}$.

Organem wykonawczym w gminie rumuńskiej jest mer. Realizuje on zarówno zadania urzędnika państwowego, jak i pracownika samorządowego. Stąd jego dwuszczeblowa odpowiedzialność - w sprawach z zakresu administracji państwowej przed rządem, a w dziedzinie lokalnych spraw samorządowych przed radą gminną. Do pierwszego katalogu kompetencji mera należą sprawy: zapewnienie praw obywatelskich, wykonywanie ustaw, dekretów i poleceń rządowych, decyzji ministrów, utrzymanie porządku publicznego na terenie gminy. $Z$ drugiego katalogu spraw należy wymienić: realizację decyzji rady lokalnej, wykonanie lokalnego budżetu, zatrudnianie i zwalnianie personelu administracyjnego ${ }^{56}$.

Ustawodawstwo samorządowe zostało wprowadzone w Rumunii dopiero jesienią 1991 r. po uchwaleniu nowego aktu konstytucyjnego. W pierwszym okresie istnienia władz samorządowych zwracano uwagę na liczne ograniczenia instytucjonalne, personalne i fiskalne w wykonywaniu swoich zadań. Za kwestię bardzo kontrowersyjną uznawano również zasięg kontroli ze strony prefektów nad radami samorządowymi. Bardzo często (szczególnie w pierwszym okresie funkcjonowania samorządów) postrzegano instytucję prefekta jako władzę nadrzędną dla zgodnego z prawem zawieszania lub wpływania na proces prawotwórczy w radach gminnych. Inną istotną kwestią jest zależność dochodów administracji lokalnej od dotacji pochodzącej z budżetu centralnego. Duże zaniepokojenie wywoływały pensje personelu administracji samorządowej. Uważano ich wysokość za tak niską (ustalano je początkowo na szczeblu centralnym), iż zniechęcało to młodych i utalentowanych ludzi do wyboru kariery w administracji lokalnej ${ }^{57}$.

${ }_{55}$ Zob. R. Radek, Samorzad terytorialny w Republice Rumunii, [w:] Samorzad terytorialny..., s. 60 oraz S. Balík, Komunální..., s. 148.

${ }_{56}$ Zob. A. Burakowski, System polityczny współczesnej Rumunii, Kraków 2014.

${ }^{57}$ Zob. M. Farcas, Podstawowe informacje o wladzach lokalnych w Rumunii, [w:] Wtadze lokalne w Europie Centralnej $i$ Wschodniej..., s. 174. 
Jak zwracają uwagę analitycy funkcjonowania rumuńskiej administracji publicznej, po obaleniu dyktatury klanu Ceauşescu w grudniu 1989 r. pierwszorzędną kwestią było zwiększenie zakresu jej decentralizacji oraz dekoncentracji warunków działania służb publicznych. Reformy decentralizacyjne obejmowały również kwestie doprecyzowania szczegółowych terminów administracyjnych, związanych z podziałem terytorialnym, ramami administracyjnymi, jak i przyporządkowanymi im konkretnymi uprawnieniami ${ }^{58}$.

Zasadnicze zmiany w funkcjonowaniu administracji lokalnej wynikały z ubiegania się przez Rumunię o członkostwa w instytucjach europejskich. W kwietniu 2001 r. parlament uchwalił ustawę o publicznej administracji lokalnej, a w marcu 2004 r. nową ustawę o wyborach do władz publicznej administracji lokalnej ${ }^{59}$. Rozdzielały one w sposób bardziej precyzyjny kompetencje i uprawnienia administracji centralnej oraz lokalnej i miały dawać większy zakres autonomii funkcjonującym od 1990 r. władzom lokalnym.

\section{Bibliografia}

Administracja publiczna u progu XXI wieku: wyzwania i oczekiwania, red. J. Osiński, Warszawa 2011.

Babčák V., Władza lokalna w Republice Stowackiej, [w:] Wtadza i finanse lokalne w Polsce $i$ krajach ościennych, red. E. Ruśkowski, B. Dolnicki, Bydgoszcz-Białystok -Katowice 2007.

Balík S., Komunální politika, Praha 2009.

Barański M., Samorzad terytorialny w Republice Stowacji, [w:] Samorzad terytorialny w Europie Środkowej i Wschodniej, red. M. Barański, Katowice-Torun 2009.

Barański M., Stowacja. Podstawy ustrojowe systemu politycznego. Partie polityczne w stowackim parlamencie, [w:] Dynamika systemów politycznych wybranych państw Europy Środkowej i Wschodniej, red. M. Barański, Katowice 1995.

Benuška P., Reforma samorządowa w Republice Czeskiej i Stowackiej, [w:] Demokracja lokalna w krajach Europy Środkowo-Wschodniej, red. A. Miszczuk, Lublin 1995.

Blažek J., Czynniki i kierunki rozwoju regionalnego Republiki Czeskiej podczas transformacji i w okresie przedakcesyjnym, „Samorząd Terytorialny” 2004, nr 2.

Brodziński W., System konstytucyjny Rumunii, Warszawa 2006.

Brodziński W., System konstytucyjny Węgier, Warszawa 2003.

Bröstl A. a kolektív, Ústavné právo Slovenskej republiky, Plzeň 2010.

Bułgaria. Przemiany konstytucyjne w Europie Wschodniej, t. I, red. R. Chruściak, Warszawa 1993.

Burakowski A., System polityczny wspótczesnej Rumunii, Kraków 2014.

${ }^{58}$ Zob. O. Aron, Wyzwania dla rumuńskiej administracji publicznej po 1989 roku, [w:] Dwie dekady zmian. Rumunia 1989-2009, red. K.P. Marczuk, Warszawa 2009, s. 57.

${ }_{59}$ Monitorul Oficial, nr 204 z 2001 r.; nr 271 z 2004 r. 
Bure J., Charvát J., Just P., Štefek M., Česká demokracie po roce 1989. Institucionální základyčeského politického systemu, Praha 2012.

Capkova S., Podstawowe informacje o władzach lokalnych na Stowacji, [w:] Władze lokalne w Europie Centralnej i Wschodniej oraz we Wspólnocie Niepodległych Państw, Budapeszt 1994.

Chmielewski G., System konstytucyjny Stowacji, Warszawa 2014.

Chrabąsz R., Hausner J., Mazur S., Administracja publiczna w wybranych krajach Europy Środkowowschodniej, Kraków 2003.

Czyż A., Samorząd terytorialny w państwach Grupy Wyszehradzkiej, Dąbrowa Górnicza 2010.

Czyż A., Samorząd terytorialny w Republice Wegier, [w:] Samorzad terytorialny w Europie Środkowej i Wschodniej, red. M. Barański, Katowice-Torun 2009.

Czyż A., Glajcar R., Krysieniel K., Wegry, [w:] Władza państwowa i administracja publiczna w państwach Europy Środkowej i Wschodniej, red. M. Barański, Torun 2007.

Czyż A., Rduch-Michalik T., Samorząd terytorialny w Republice Czeskiej, [w:] Samorząd terytorialny w Europie Środkowej i Wschodniej, red. M. Barański, Katowice-Toruń 2009.

Demokracja lokalna w państwach Europy, red. I. Bokszczanin, A. Mirska, Warszawa 2014.

Farcas M., Podstawowe informacje o władzach lokalnych w Rumunii, [w:] Władze lokalne w Europie Centralnej $i$ Wschodniej oraz we Wspólnocie Niepodległych Państw, Budapeszt 1994.

Horvath T.M., Podstawowe informacje o władzach lokalnych na Wegrzech, [w:] Władze lokalne w Europie Centralnej i Wschodniej oraz we Wspólnocie Niepodlegtych Państw, Budapeszt 1994.

Jakubowska A., Czechy, [w:] Nowa dziesiątka Unii Europejskiej, red. D. Jędrzejczyk, Warszawa 2005.

Kaczmarek T., Struktury terytorialno-administracyjne i ich reformy $w$ krajach europejskich, Poznań 2005.

Kaczmarska E., Słowacja, [w:] Nowa dziesiątkaUnii Europejskiej, red. D. Jędrzejczyk, Warszawa 2005.

Karp J., Grzybowski M., System konstytucyjny Bułgarii, Warszawa 2002.

Koseski A., Butgarska transformacja, [w:] Przemiany w Europie Środkowo-Wschodniej. 20 lat doświadczeń, red. A. Koseski, J. Wojnicki, Pułtusk 2011.

Koseski A., Willaume M., Nowe kraje Unii Europejskiej. Bułgaria, Rumunia,Warszawa 2007.

Kulesza M., Sześciło D., Polityka administracyjna i zarządzanie publiczne, Warszawa 2013.

Kyutchukov S., Podstawowe informacje o władzach lokalnych $w$ Republice Bułgarii, [w:] Władze lokalne w Europie Centralnej $i$ Wschodniej oraz we Wspólnocie Niepodlegtych Państw, Budapeszt 1994.

Lacina K., Podstawowe informacje o wtadzach lokalnych $w$ Republice Czeskiej, [w:] Wtadze lokalne w Europie Centralnej $i$ Wschodniej oraz we Wspólnocie Niepodlegtych Państw, Budapeszt 1994.

Lacina K., Vajdova Z., Local goverment in the Czech Republic, [w:] Decentralization: Experiments and Reform. Local Governms in Central and Eastern Europe, ed. T.M. Horváth, Budapest 2000.

Láštic E., Územná samospráva, Bratislava 2010.

Leoński Z., Samorząd terytorialny w Czechach, ,Samorząd Terytorialny” 1993, nr 1/2. 
Leoński Z., Ustrój organów administracji lokalnej na szczeblu powiatu w Czechach, „Samorząd Terytorialny" 1994, nr 5.

Mrkývka P., Władza lokalna w Republice Czeskiej, [w:] Władza i finanse lokalne w Polsce $i$ krajach ościennych, red. E. Ruśkowski, B. Dolnicki, Bydgoszcz-Białystok -Katowice 2007.

Nemec J., Bercik P., Kuklis P., Local Goverment in Slovakia, [w:] Decentralization: Experiments and Reform. Local Governms in Central and Eastern Europe, ed. T.M. Horváth, Budapest 2000.

Olejniczak-Szałowska E., Zadania i ustrój samorządu terytorialnego na Węgrzech, „Samorząd Terytorialny" 1992, nr 9.

Pioskowik E., Bułgaria. Rola organów przedstawicielskich w systemie rzadów na szczeblu centralnym i terenowym, [w:] Dynamika systemów politycznych wybranych państw Europy Środkowej i Wschodniej, red. M. Barański, Katowice 1995.

Pioskowik E., Władza lokalna w Bułgarii, [w:] Władze lokalne w Europie Środkowej $i$ Wschodniej. Gmina. Region. Samorzą, red. M. Barański, Katowice 1998.

Posluch M., Cibulka L', Štátne právo Slovenskej republiky, Šamorín 2006.

Radek R., Samorzad terytorialny w Republice Rumunii, [w:] Samorzad terytorialny w Europie Środkowej i Wschodniej, red. M. Barański, Katowice-Torun 2009.

Rduch-Michalik T., Czechy, [w:] Władza państwowa i administracja publiczna w państwach Europy Środkowej i Wschodniej, red. M. Barański, Torun 2007.

Rduch-Michalik T., Władze lokalne w Republice Czeskiej, [w:] Władze lokalne w Europie Środkowej i Wschodniej. Gmina. Region. Samorzą, red. M. Barański, Katowice 1998.

Regulski J., Samorząd III Rzeczypospolitej: koncepcje i realizacja, Warszawa 2000.

Rosłonek A., Wegry, [w:] Nowa dziesiatka Unii Europejskiej, red. D. Jędrzejczyk, Warszawa 2005.

Rydlewski G., Systemy administracji publicznej w państwach członkowskich Unii Europejskiej, Warszawa 2007.

Skrzydło W., Republika Rumunii, [w:] Ustroje państw współczesnych, t. 2, red. E. Gdulewicz, Lublin 2002.

Skotnicki K., System konstytucyjny Czech, Warszawa 2000.

Swianiewicz P., Reformy konsolidacji terytorialnej - teoria i praktyka krajów Europy Środkowo-Wschodniej, „Samorząd Terytorialny” 2009, nr 4.

Swianiewicz P., Stymulowanie lokalnej przedsiębiorczości, poprawa warunków bytu ludności czy pobożne życzenia? Charakterystyka polityk lokalnych $w$ krajach Europy Środkowo-Wschodniej, [w:] Demokracja lokalna w krajach Europy Środkowo-Wschodniej, red. A. Miszczuk, Lublin 1995.

Temesi I., Local Goverment in Hungary, [w:] Decentralization: Experimentsand Reform. Local Governms in Central and Eastern Europe, ed. T.M. Horváth, Budapest 2000.

Vodička K., Cabada L., Politický system České republiky. Historie a současnost, Praha 2011. Wojnicki J., Decentralizacja władzy publicznej w państwach Europy Środkowo-Wschodniej: aspekt ustrojowo-politologiczny, Warszawa 2014.

Zieliński E., Administracja rzadowa i samorzadowa w Polsce, Warszawa 2013.

Żmigrodzki M., Administracja publiczna i samorzad terytorialny $w$ Republice Bułgarii, [w:] Demokracja lokalna $w$ krajach Europy Środkowo-Wschodniej, red. A. Miszczuk, Lublin 1995. 


\section{Jacek Wojnicki}

\section{Реституция местного и регионального самоуправления в государствах Центральной и Восточной Европы}

Статья посвящена восстановлению местного и регионального самоуправления в странах Центральной и Восточной Европы. Он показывает основные направления формирования администрации местного самоуправления в обсуждаемых посткоммунистических странах. Предметом анализа является группа из пяти стран: Чехия, Словакия, Венгрия, Болгария и Румыния. Иногда на фоне представленных анализов самоуправления мы также находим польские темы.

Ключевые слова: локальное правительство, воеводское самоуправление, децентрализация, администрация, реформа публичной администрации.

\section{Jacek Wojnicki}

\section{The restoration of local and regional self-governments in the countries of Central and Eastern Europe}

The article is devoted to the restoration of local and regional self-governments in the countries of Central and Eastern Europe. The author shows the main directions of formation the local government administration in the post-communist countries. The main subject of the analysis is a group of five countries: the Czech Republic, Slovakia, Hungary, Bulgaria and Romania. The article also presents some Polish aspects of creating self-government structures.

Keywords: local government, voivodeship self-government, decentralization, administration, public administration reform. 